\title{
Moisture content thresholds for ignition and rate of fire spread for various dead fuels in northeast forest ecosystems of China
}

\author{
Maombi Mbusa Masinda ${ }^{1,2} \cdot$ Long Sun ${ }^{1}$. \\ Guangyu Wang ${ }^{3}$ Tongxin $\mathrm{Hu}^{1}$
}

Received: 22 February 2020 / Accepted: 8 April 2020 / Published online: 5 June 2020

(C) The Author(s) 2020

\begin{abstract}
Fuel moisture content is one of the important factors that determine ignition probability and fire behaviour in forest ecosystems. In this study, ignition and fire spread moisture content thresholds of 40 dead fuel were performed in laboratory experiments, with a focus on the source of ignition and wind speed. Variability in fuel moisture content at time of ignition and during fire spread was observed for different fuels. Matches were more efficient to result in ignition and spread fire with high values of fuel moisture content compared to the use of cigarette butts. Some fuels did not ignite at $15 \%$ moisture content, whereas others ignited at $40 \%$ moisture content and fire spread at $38 \%$ moisture content in the case of matches, or ignited at $27 \%$ moisture
\end{abstract}

Project funding: This research was funded by the National

Key Research and Development Program of China

(2018YFE0207800), the Fundamental Research Funds for the

Central Universities (2572019CP10), the National Innovation

Alliance of Wildland Fire Prevention and Control Technology

of China, and the Northern Forest Fire Management Key

Laboratory of the State Forestry and Grassland Bureau.

The online version is available at http://www.springerlink.com.

Corresponding editor: Yu Lei.

Electronic supplementary material The online version of this article (https://doi.org/10.1007/s11676-020-01162-2) contains supplementary material, which is available to authorized users.

Long Sun

sunlong365@126.com

Tongxin $\mathrm{Hu}$

htxhtxapple@sina.com

1 Key Laboratory of Sustainable Forest Ecosystem Management-Ministry of Education, College of Forestry, Northeast Forestry University, 26 Hexing Road, Harbin 150040, People's Republic of China content and spread fire at 25\% moisture content using cigarette butts. A two-way ANOVA showed that both the source of ignition and the wind speed affected ignition and fire spread threshold significantly, but there was no interaction between these factors. The relationship between ignition and fire spread was strong, with $\mathrm{R}^{2}=98 \%$ for cigarette butts, and $92 \%$ for matches. Further information is needed, especially on the density of fuels, fuel proportion (case of mixed fuels), fuel age, and fuel combustibility.

Keywords Dead fuel - Ignition source · Wind speed · Ignition moisture threshold · Propagation moisture threshold

\section{Introduction}

Understanding the appropriate forest policy and how it should be implemented is crucial for protecting fragile ecosystems and preserving ecosystem services (Alessio et al. 2008). In this respect, forest fires have been extensively studied at specific spatial scales at which climate conditions interact with the fuel load and moisture content, composition, and spatial distribution to affect ignition and fire behaviour (Allen et al. 2016). However, indices that determine whether a fire can be controlled or whether it will expand

2 Faculty of Sciences, Université Officielle de Ruwenzori, PO Box 560, Butembo, North Kivu, Democratic Republic of the Congo

3 Heilongjiang Vocational Institute Ecological Engineering, Harbin, Heilongjiang Province, People's Republic of China 
and have disastrous impacts have not been measured in some forest areas. Thus, identifying and quantifying the critical thresholds of determinant factors of forest fire behavior is crucial for fuel management, fire prevention, and suppression (Liu et al. 2013).

Anthropogenic activities have significantly increased the occurrence and extent of wildland fires (Ying et al. 2018), and over the last five decades, wildland fires have become a major danger to many countries and regions such as Canada, the United States, central Chile, South Africa, Russia, Southern Australia, the Mediterranean Basin (Figueroa et al. 2019), the northeast and southeast of China (Wu et al. 2011), and most recently in Brazil (August 2019) and Australia (December 2019). Fire ignition and spread are a process of various interdependent components, including fuel moisture content (Madrigal et al. 2009). (Nelson 2001) identified three effects of fuel moisture content levels on reducing the rate of fuel combustion-increasing the time for ignition, reducing fuel consumption, and raising the residence time of burning particles. Finney et al. (2010) and Syphard et al. (2019) demonstrated that fuel moisture content, wind speed, and fuel load are the main factors that control fire behaviour, and Possell and Bell (2013) reported that fuel moisture content is the most critical factor affecting fire ignition. However, McAllister and Weise (2017) showed that this alone cannot explain the ignition behaviour of fuels. In addition to these findings, Rossa (2018) provided several more determinants considered as key variables for measuring the risk of ignition and fire spread, including fuel load and its moisture content, topography, wind speed and direction, relative humidity, and air temperature.

Plucinski et al. (2010) noted that information on ignition moisture threshold of fuels is important for scheduling and implementing prescribed burning. In the same study, they showed that many attempts at prescribed burning of shrubland vegetation resulted in ignition failures due to the narrow window for successful controlled burning. In addition, Nolan et al. (2016) advocated that, during prescribed burning, fire managers should ensure that the moisture content of the dead fuels are sufficient for the fuels to be burned and that the moisture content of live fuel is sufficiently high so that the fire cannot ignite and spread into the crown. Therefore, an understanding of the relationship between fuel moisture content (FMC), ignition and fire spread is needed to improve current understanding of forest fire behavior, in particular by estimating the FMC threshold at which ignition can occur and fire can spread in forest ecosystems (Fletcher et al. 2007).

Forest fire management requires prevention and fire risk assessment systems by providing accurate and timely information on fire potential for all basic fuel types (Allen et al. 2016). In this context, ignitability and combustibility ranking of forest species, the most significant fuel types, are essential components in fire prevention and fire risk management (Dimitrakopoulos 2001; Plucinski et al. 2010). Each fuel species has its own narrow and distinct threshold, below which it may ignite but will not spread, but beyond which ignition develops into fire spread with high intensity (Anderson and Anderson 2010). For this reason, knowledge on fuel conditions in forest ecosystems may constitute an effective means of preventing or managing forest fires (Ganteaume et al. 2011).

Studies on the moisture content of ignition fuels started about five decades ago (Dimitrakopoulos 2001). Since the 1970s, U.S. researchers have been developing a measurement of the flammability of various types of forest fuels (Anderson 1970). Other studies have been conducted in Australia and the Mediterranean region. For example, Alessio et al. (2008), Anderson and Anderson (2010), and Dimitrakopoulos and Papaioannou (2001) focused on estimating the ignition moisture content threshold of several mixed species of fuels. In China, forest fires are reported from the subtropics through temperate zones to the boreal zone ( $\mathrm{Li}$ et al. 2015; Guo et al. 2017; Su et al. 2019). Daxing' anling is the largest area of boreal forests in China, which is sensitive to climate change. From 2004-2014, 240 fire occurrences were recorded at Daxing' anling, burning over 385,725 ha of forest (Su et al. 2019). Yang et al. (2011) hypothesized that the number of days with extremely high fire danger in Daxing'anling would increase from 44 days (in the 1980s) to 53-75 days by the end of the 21st century due to climate change. Xiaoxing' anling Forest is a forested area in northeast China, famous for ecotourism. Like many forested tourist areas in China, numerous wildfires occur in Xiaoxing' anling, mainly caused by human factors (Su et al. 2018). Therefore, research is needed to improve understanding of the effect of fuel moisture levels on the flammability and combustibility of forest floor fuels in fire risk management, and to provide sustainable silvicultural interventions against wildfires.

The spread of fire is uncertain when moisture content of dead fuels is between 10-40\% (Rothermel 1972). Similarly, U.S., Canadian, and Austrian forest management researchers have developed indices used in several studies to assess their validity in fire risk and management. However, there are inconsistencies in some areas, given the particularities of different forest ecosystems (Nelson and Hiers 2008). In China, there is no documentation on fuel moisture ignition thresholds and rate of fire spread and therefore, this study extended its scope to several fuel types in the northeast of the country where fires have been reported and still occur.

The main objective was to determine the maximum fuel moisture threshold that could trigger ignition through lite cigarette butts and matches (human action), and spread the fire. The specific objectives were: (1) to define the moisture content thresholds for ignition and fire spread of various 
dead fuels of Daxing'anling and Xiaoxing' anling forest ecosystems; (2) to determine the influence of wind speed and source of ignition on ignition and fire spread; and, (3) to establish the relationship between ignition and fire spread in forest ecosystems.

\section{Materials and methods}

\section{Study locations}

This study was conducted in the Daxing'anling and Xiaoxing'anling forests in Heilongjiang province in the northeast of China (Fig. 1).

The first site, Daxing' anling (Tahe), is located at $123^{\circ} 56^{\prime}$ E, $52^{\circ} 27^{\prime} \mathrm{N}$ and is characterised as a continental monsoon climate, with long, cold dry winters due to the Siberian cold air mass; a fresh and short spring and autumn; and a short summer with significant variations in temperature and rainfall (Hu et al. 2019). The yearly average precipitation and temperature are $463 \mathrm{~mm}$ and $-2.3{ }^{\circ} \mathrm{C}$, respectively, and the frost-free period is less than 100 days. Daxing' anling vegetation is a mixed formation of boreal forest species (southern extension of boreal forests of eastern Siberia) and temperate forest species (Chang et al. 2008). Between 1965 and 2010,
1614 wildfires were recorded in the Daxing'anling forests, making the region first in terms of forest fire incidences in China (Hu et al. 2017). The Xiaoxing' anling area is located at Liangshui $\left(128^{\circ} 02^{\prime} \mathrm{E}, 47^{\circ} 12^{\prime} \mathrm{N}\right)$ and at Fenglin $\left(129^{\circ} 15^{\prime}\right.$ $\left.\mathrm{E}, 48^{\circ} 07^{\prime} \mathrm{N}\right)$. These sites are also characterised by a continental monsoon climate, with a yearly average temperature and precipitation of $-0.3{ }^{\circ} \mathrm{C}$ and $676 \mathrm{~mm}$, respectively. Summers are rainy, hot, and short. The growing season is relatively short, with $100-120$ frost-free days and soils that are frozen from December to April for about 130-150 days. Xiaoxing'anling is temperate forest with evergreen and deciduous species, the latter dominant (Liu et al. 2015).

\section{Field sampling}

Dead fuel material was collected during the autumn fire season (September 2014) in 45 quadrats in Daxing' anling and in Liangshui (September 2015) and Fenglin (September 2016) of Xiaoxing' anling. Fifteen representative forest ecosystems were selected from sampling site. In each ecosystem, three plots were randomly set out and five $16 \mathrm{~m}^{2}$ subplots installed for fuel sample collection. The samples were moved to the laboratory kept in a climate chamber at 25 ${ }^{\circ} \mathrm{C}$ and $50 \%$ relative humidity and away from direct sunlight. A total of 40 samples were recorded instead of 45 (from 15

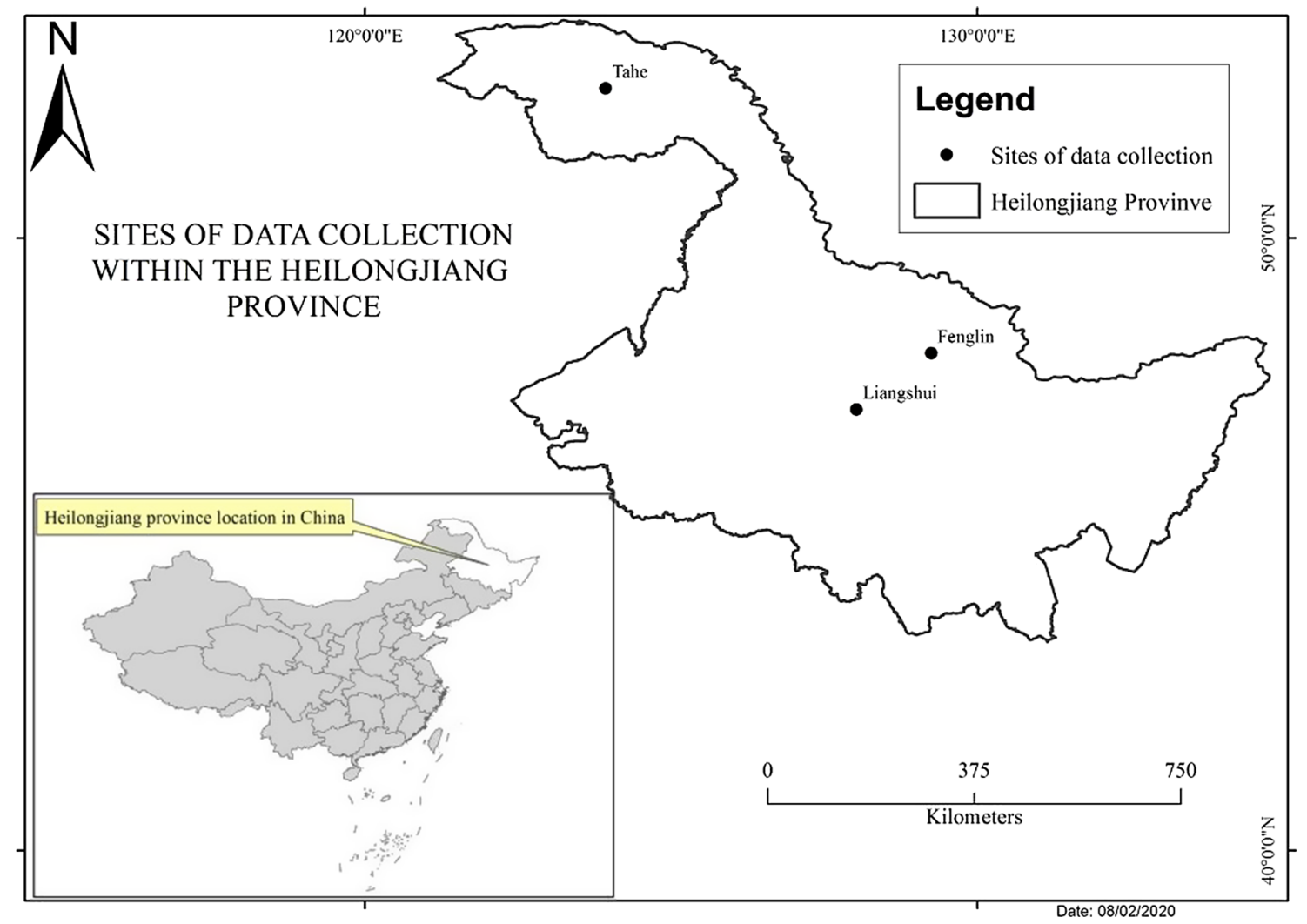

Fig. 1 Study location 
forest ecosystems $\times 3$ sampling sites), as some ecosystems were common to two or three sites (Daxing' anling and Tahe; Xiaoxing'anling, Liangshui and Fenglin).

\section{Experimental design and laboratory tests}

Fuel moisture content was calculated in the laboratory as measurement under field conditions is difficult to evaluate due to the presence of live fuel on the ground surface (Davies and Legg 2011). In the laboratory, before the burning process, for each fuel sample, three $100 \mathrm{~g}$ sub-samples were oven dried at $105{ }^{\circ} \mathrm{C}$ for $48 \mathrm{~h}$ to determine dry mass. Samples were placed on experimental trays enclosed in a burning unit. The fuel moisture content (FMC) was calculated by the gravimetric method:

$F M C=\frac{W_{w}-W_{d}}{W_{d}} \times 100$

where $W_{w}$ is the wet weight and $W_{d}$ the dry weight of fuel

Each test was repeated five times for each combination of variables (source of ignition and wind speed) in order to reduce uncertainties and obtain a valid dataset (Jervis and Rein 2016). Before each ignition, steady-state conditions of the air-flow angle and wind speed were checked. The burning process was carried out for 40 dead fuel samples using matches as in Larjavaara et al. (2004), and cigarette butts as in Sun et al. (2018). Two independent variables were considered: source of ignition, and wind speed. The source of ignition had two variants, matches and cigarette butts.

During autumn, wind speed in the region does not exceed $15 \mathrm{~km} / \mathrm{h}$. Therefore, three wind speeds between 10 and 15 $\mathrm{km} / \mathrm{h}$, corresponding to the intervals of maximum wind speeds in the region during the fall season, were considered. The speeds selected were $10 \mathrm{~km} / \mathrm{h}\left(2.77 \mathrm{~m} \cdot \mathrm{s}^{-1}\right), 12$ $\mathrm{km} / \mathrm{h}\left(3.33 \mathrm{~m} \cdot \mathrm{s}^{-1}\right)$, and $14 \mathrm{~km} / \mathrm{h}\left(3.89 \mathrm{~m} \cdot \mathrm{s}^{-1}\right)$. A fan was used to simulate wind speed and was installed $1.5 \mathrm{~m}$ from the experimental tray. The air-flow to the tray was adjusted to $45^{\circ}$ to prevent fuel particles from blowing away (Marino et al. 2010). The highest slope in the study region is $45^{\circ}$ and was considered the critical slope. High wind speed and slope values were considered according to the site's configuration to measure impact on fire ignition and spread. The dependent variables were the maximum fuel moisture content at ignition and rate of spread of the fire.

Ignition of fuel samples was considered successful when the flame was sustained and extended beyond the initial point of ignition, and unsuccessful when the flame was extinguished at the contact point or in a short time (Anderson 1970). The ignition source was applied for 2-3 min at 15 and $25^{\circ} \mathrm{C}$ but relative humidity was not measured. In addition, fire spread was regarded as successful if the flames spread more than $20 \mathrm{~cm}$ from the contact point. The average time for each test was $17.5 \mathrm{~min}$. The ignition potential was not taken into account because, if after 5-20 tests the fuel did not ignite, it was discarded.

\section{Statistical analysis}

The Student $t$ test was used to compare the moisture content at ignition and fire spread using both source of ignition and wind speed. The test was considered significant at $p<0.05$. Data distribution was normalised using log-transformation, and the effect of the ignition source and wind speed were analysed by two-way ANOVA. Tukey's test in STATISTICA 12.5.192.7 (StatSoft Inc., Tulsa, OK, USA) was used to investigate differences in ignition when calibrating different wind speeds $\left(2.77,3.33\right.$, or $\left.3.89 \mathrm{~m} \cdot \mathrm{s}^{-1}\right)$. Spearman correlations for wind speed, ignition source, and moisture content thresholds were calculated. Statistical analyses were carried out with RStudio (RStudio Team 2018; Integrated Development for RStudio, Inc., Boston, MA), and the ignition and fire spread relationship graph was built with Origin software (Origin 2018; Origin 9.5. OriginLab Corp., Northampton, MA, USA) (Fig. 2).

\section{Results}

Fuel moisture content varied at the point of ignition and in rate of fire spread for different species (Table 1). The moisture content of fuels ignited by matches ranged from $13.7 \% \pm 2.2 \%$ (Syringa reticulana) to $40.4 \pm 2.5 \%$ (Betula costata), and $10.5 \pm 1.1 \%$ to $27.5 \pm 1.7 \%$ for cigarette butts. For rate of fire spread, moisture content varied from $11.0 \% \pm 1.2 \%$ to $38.9 \% \pm 1.2 \%$ for matches and from $9.6 \pm 1.2 \%$ to $27.4 \pm 1.5 \%$. Betula costata fuels ignited and

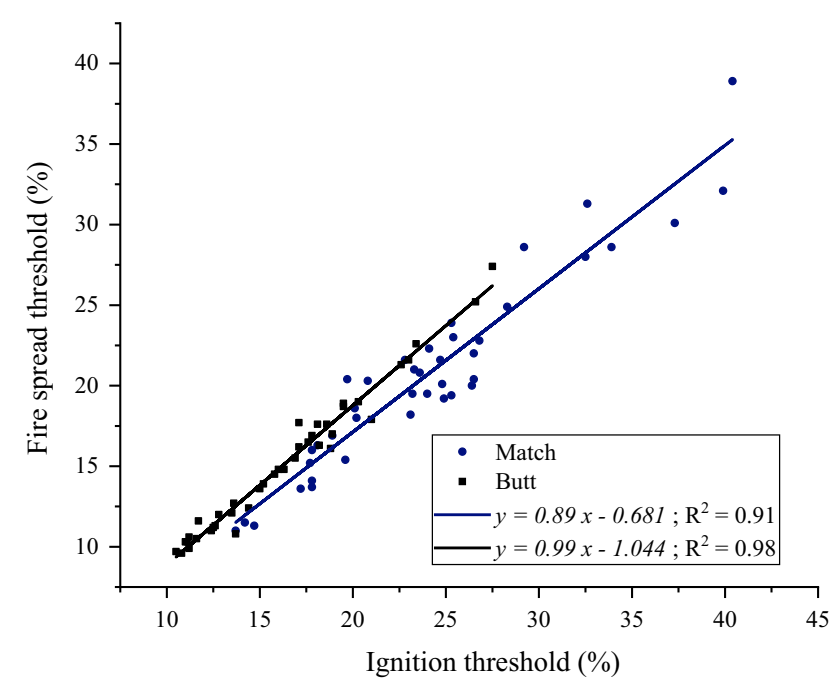

Fig. 2 Ignition and fire spread moisture threshold relationship 
Table 1 Moisture content thresholds for ignition and fire spread

\begin{tabular}{|c|c|c|c|c|c|c|}
\hline Fuel species & $\begin{array}{l}\text { Ignition mois- } \\
\text { ture match } \\
(\%)\end{array}$ & $\begin{array}{l}\text { Ignition } \\
\text { moisture } \\
\text { butt }(\%)\end{array}$ & $\begin{array}{l}\text { Spread mois- } \\
\text { ture match } \\
(\%)\end{array}$ & $\begin{array}{l}\text { Spread } \\
\text { moisture } \\
\text { butt (\%) }\end{array}$ & $\begin{array}{l}\text { Ignition versus } \\
\text { spread moisture for } \\
\text { Match }\end{array}$ & $\begin{array}{l}\text { Ignition versus } \\
\text { spread moisture } \\
\text { for butt }\end{array}$ \\
\hline Betula costata Trautv & $40.4 \pm 2.5$ & $26.6 \pm 4.0$ & $38.9 \pm 1.2$ & $25.2 \pm 3.7$ & 1.5 & 1.4 \\
\hline Picea koraiensis Nakai & $39.9 \pm 4.5$ & $27.5 \pm 1.7$ & $32.1 \pm 1.8$ & $27.4 \pm 1.5$ & 7.8 & 0.1 \\
\hline Acer tegmentosum Maxim & $37.3 \pm 3.0$ & $23.4 \pm 1.4$ & $30.1 \pm 1.2$ & $22.6 \pm 1.7$ & 7.2 & 0.8 \\
\hline Pinus sylvestris L. & $33.9 \pm 6.6$ & $22.6 \pm 3.5$ & $28.6 \pm 2.5$ & $21.3 \pm 2.8$ & 5.3 & 1.3 \\
\hline Juglans mandshurica Maxim & $32.6 \pm 4.2$ & $17.1 \pm 1.3$ & $31.3 \pm 3.9$ & $16.2 \pm 1.9$ & 1.3 & 0.9 \\
\hline Pinus koraiensis Siebold \& Zucc. & $32.5 \pm 3.8$ & $23.0 \pm 4.4$ & $28.0 \pm 2.8$ & $21.6 \pm 4.1$ & 4.5 & 1.4 \\
\hline Fraxinus mandshurica Rupr. & $29.2 \pm 2.0$ & $18.6 \pm 1.9$ & $28.6 \pm 2.1$ & $17.6 \pm 2.4$ & 0.6 & 1.0 \\
\hline Larix gmelinii Rupr. & $28.3 \pm 3.0$ & $19.5 \pm 1.2$ & $24.9 \pm 3.0$ & $18.9 \pm 1.0$ & 3.4 & 0.6 \\
\hline $\begin{array}{l}\text { Betula platyphylla Sukaczev and } \\
\text { Quercus mongolica Fisch. }\end{array}$ & $26.8 \pm 1.9$ & $18.8 \pm 1.4$ & $22.8 \pm 3.8$ & $16.1 \pm 2.6$ & 4.0 & 2.7 \\
\hline Acer mono H.Ohashi & $26.5 \pm 6.3$ & $11.7 \pm 0.7$ & $20.4 \pm 2.5$ & $11.6 \pm 1.4$ & 6.1 & 0.1 \\
\hline Quercus mongolica Fisch. & $26.5 \pm 2.5$ & $17.8 \pm 2.7$ & $22.0 \pm 2.4$ & $16.9 \pm 2.0$ & 4.5 & 0.9 \\
\hline Ulmus pumila $\mathrm{L}$. & $26.4 \pm 3.1$ & $18.1 \pm 3.4$ & $20.0 \pm 2.2$ & $17.7 \pm 1.7$ & 6.4 & 0.4 \\
\hline Pinus tabuliformis Carr. & $25.4 \pm 0.4$ & $20.3 \pm 2.2$ & $23.0 \pm 2.0$ & $19.0 \pm 2.7$ & 2.4 & 1.3 \\
\hline Tilia amurensis Rupr. & $25.3 \pm 2.7$ & $13.6 \pm 3.5$ & $23.9 \pm 2.0$ & $12.7 \pm 3.7$ & 5.9 & 1.3 \\
\hline $\begin{array}{l}\text { Populus davidiana Dode and Quercus } \\
\text { mongolica Fisch. }\end{array}$ & $25.3 \pm 1.8$ & $15.2 \pm 1.6$ & $19.4 \pm 2.0$ & $13.9 \pm 2.1$ & 1.4 & 0.9 \\
\hline Ulmus laciniata Mayr & $24.9 \pm 2.3$ & $18.9 \pm 1.5$ & $19.2 \pm 0.9$ & $17.0 \pm 1.4$ & 4.7 & 1.2 \\
\hline Abies nephrolepis Maxim. & $24.8 \pm 2.3$ & $16.0 \pm 1.4$ & $20.1 \pm 1.3$ & $14.8 \pm 2.2$ & 3.1 & 1.4 \\
\hline $\begin{array}{l}\text { Ledum palustre L. and Larix gmelinii } \\
\text { Rupr. }\end{array}$ & $24.7 \pm 1.4$ & $15.0 \pm 1.4$ & $21.6 \pm 1.0$ & $13.6 \pm 2.0$ & 1.8 & 3.1 \\
\hline $\begin{array}{l}\text { Rhododendron and Larix gmelinii } \\
\text { Rupr. }\end{array}$ & $24.1 \pm 1.7$ & $21.0 \pm 3.0$ & $22.3 \pm 2.5$ & $17.9 \pm 2.4$ & 4.5 & 0.8 \\
\hline Betula platyphylla Sukaczev & $24.0 \pm 2.0$ & $19.5 \pm 2.2$ & $19.5 \pm 1.8$ & $18.7 \pm 3.6$ & 5.7 & 1.9 \\
\hline Deyeuxia langsdorffii Kunth & $23.6 \pm 2.1$ & $13.7 \pm 1.1$ & $20.8 \pm 3.0$ & $10.8 \pm 1.8$ & 2.8 & 2.9 \\
\hline Ulmus sp & $23.3 \pm 2.6$ & $18.2 \pm 1.8$ & $21.0 \pm 1.2$ & $16.3 \pm 2.4$ & 2.3 & 1.9 \\
\hline $\begin{array}{l}\text { Pinus koraiensis L. and Betula platy- } \\
\text { phylla Sukaczev }\end{array}$ & $23.2 \pm 1.2$ & $16.9 \pm 2.6$ & $19.5 \pm 0.9$ & $15.5 \pm 2.0$ & 3.7 & 1.4 \\
\hline $\begin{array}{l}\text { Pinus sylvestris L. and Betula platy- } \\
\text { phylla Sukaczev }\end{array}$ & $23.1 \pm 2.4$ & $15.8 \pm 1.8$ & $18.2 \pm 3.8$ & $14.5 \pm 2.4$ & 4.9 & 1.3 \\
\hline Grass and Larix gmelinii Rupr. & $22.8 \pm 1.3$ & $18.1 \pm 1.0$ & $21.6 \pm 2.0$ & $17.6 \pm 1.1$ & 1.2 & 0.5 \\
\hline Tilia mandshurica $\mathrm{L}$. & $20.8 \pm 6.0$ & $11.6 \pm 2.0$ & $20.3 \pm 6.0$ & $10.5 \pm 2.0$ & 0.5 & 1.1 \\
\hline $\begin{array}{l}\text { Larix gmelinii Rupr. and Betula platy- } \\
\text { phylla Sukaczev }\end{array}$ & $20.2 \pm 0.9$ & $17.6 \pm 1.1$ & $18.0 \pm 1.3$ & $16.5 \pm 1.9$ & 2.2 & 1.1 \\
\hline Alnus hirsuta Moench & $20.1 \pm 2.1$ & $10.8 \pm 1.0$ & $18.6 \pm 2.4$ & $09.6 \pm 1.2$ & 1.5 & 1.2 \\
\hline Chosenia arbutifolia A.K.Skvortsov & $19.7 \pm 2.8$ & $12.5 \pm 1.8$ & $20.4 \pm 5.3$ & $11.2 \pm 1.2$ & 1.3 & 1.3 \\
\hline Viburnum dilatatum Thunb. & $19.6 \pm 2.7$ & $13.5 \pm 0.7$ & $15.4 \pm 5.5$ & $12.1 \pm 0.8$ & 4.2 & 1.4 \\
\hline $\begin{array}{l}\text { Ulmus davidiana Planch. var. Japónica } \\
\text { (Rehd.) Nakai }\end{array}$ & $18.9 \pm 1.4$ & $16.3 \pm 0.6$ & $16.9 \pm 1.1$ & $14.8 \pm 0.7$ & 2 & 1.5 \\
\hline Rhamnus davurica Pall. & $18.1 \pm 3.2$ & $11.1 \pm 1.5$ & $16.3 \pm 2.5$ & $10.3 \pm 1.3$ & 1.8 & 0.8 \\
\hline Rhamnus sp & $17.8 \pm 3.4$ & $12.8 \pm 1.5$ & $14.1 \pm 1.4$ & $12.0 \pm 1.0$ & 1.8 & 1.3 \\
\hline Sorbus alnifolia K.Koch & $17.8 \pm 3.4$ & $14.4 \pm 2.4$ & $13.7 \pm 4.4$ & $12.4 \pm 2.2$ & 3.7 & 0.8 \\
\hline Populus simonii Carrière & $17.8 \pm 1.8$ & $11.2 \pm 2.0$ & $16.0 \pm 1.7$ & $09.9 \pm 1.7$ & 4.1 & 2.0 \\
\hline Lonicera japonica Thunb. & $17.7 \pm 6.6$ & $12.6 \pm 3.4$ & $15.2 \pm 4.8$ & $11.3 \pm 3.6$ & 2.5 & 1.3 \\
\hline Populus davidiana Dode & $17.2 \pm 0.2$ & $12.4 \pm 1.9$ & $13.6 \pm 2.0$ & $11.0 \pm 1.9$ & 3.6 & 1.4 \\
\hline Corylus mandshurica Maxim. & $14.7 \pm 1.3$ & $11.2 \pm 3.0$ & $11.3 \pm 1.6$ & $10.6 \pm 2.7$ & 3.4 & 0.6 \\
\hline Acer ginnala Maxim. & $14.2 \pm 2.0$ & $11.0 \pm 1.4$ & $11.5 \pm 1.1$ & $10.3 \pm 1.3$ & 2.7 & 0.7 \\
\hline $\begin{array}{l}\text { Syringa reticulana P.S.Green \& } \\
\text { M.C.Chang }\end{array}$ & $13.7 \pm 2.2$ & $10.5 \pm 1.1$ & $11.0 \pm 1.2$ & $09.7 \pm 0.7$ & 2.7 & 0.8 \\
\hline
\end{tabular}


spread under slightly higher thresholds of moisture content than other fuel species. Its leaves and twigs burned at a maximum moisture content of $40.4 \pm 2.5 \%$, and its ignition resulted in a fire spread of $38.9 \%$ of moisture content using matches. On the other hand, Syringa reticulana fuels ignited when the moisture content was $13.7 \%$, and resulted in a fire spread at $11.0 \%$ moisture. When moisture contents were higher than $35 \%$, the fuel did not ignite. Ignitability and combustibility analysis showed three fuel groupings: the first group is composed with broadleaf deciduous species (Betula costata, Acer tegmentosum, Juglans mandshurica), evergreen coniferous species (Picea koraiensis, Pinus sylvestris, Pinus koraiensis), and deciduous coniferous species (Larix gmelinii), had moisture content thresholds above $25 \%$ for both ignition and spread of fire; the second group (with a moisture content threshold between 20 and 25\%) was composed of mixed fuels of the first and third groups and; the third group was composed with species for which ignition and fire spread threshold were below $20 \%$. The ignition or fire spread threshold of the most flammable species was reduced when these were associated with the lower ignition threshold species. Hence, mixed plantations are less likely to burn as readily when they are composed of a mixture of less and more flammable species.

A highly significant discrepancy was observed between the ignition moisture content, and the fire spread moisture content $(t=4.04 ; p<0.001)$. The two-way ANOVA results $(p<0.001$; Tables 2 and 3) showed that wind speed and source of ignition had a significant effect on ignition and fire spread thresholds. However, there was no relationship between wind speed and source of ignition $(p=0.760$, Table $2 ; p=0.164$, Table 3 ) and may be considered independently from one another. A significant difference in wind speed on ignition and fire spread threshold was observed when the wind speed was $10 \mathrm{~km} / \mathrm{h}\left(2.77 \mathrm{~m} \mathrm{~s}^{-1}\right)$ compared to $14 \mathrm{~km} / \mathrm{h}\left(3.89 \mathrm{~m} \mathrm{~s}^{-1}\right)$. On the other hand, the effect of wind speed on ignition and fire spread did not vary significantly when increased from 10 to $12 \mathrm{~km} / \mathrm{h}$ or from 12 to $14 \mathrm{~km} / \mathrm{h}$ (test of Tukey in Table $\mathrm{S} 1$ and Table S2).

Table 4 shows that the correlation between ignition and fire spread moisture contents was high $(r=0.94)$. However, there was a moderate, negative correlation between ignition source and moisture content at ignition or rate of fire spread, and only significant between ignition source and rate of fire spread. There was a low but significant association between wind speed and moisture content at ignition or rate of fire spread.

For each ignition source, the ignition and the fire spread moisture content threshold relationship was established (Fig. 1). The relationship was strong for both sources of ignition: butts (98\%) and matches (91\%).
Table 2 Analysis of variance of ignition moisture threshold

Table 3 Analysis of variance of spread moisture threshold

Table 4 Spearman correlationcoefficient matrix of ignition moisture content threshold, spread moisture content threshold, source of energy, and wind speed

\begin{tabular}{lcllrr}
\hline & Df & Sum of squares & Mean of squares & F value & $P$-value \\
\hline Ignition source & 1 & 9.64 & 9.64 & 134.80 & $<0.001$ \\
Wind speed & 2 & 2.39 & 2.39 & 33.44 & $<0.001$ \\
Source of ignition * & 2 & 0.01 & 0.01 & 0.09 & 0.760 \\
$\quad$ Wind speed & & & & & \\
Residuals & 266 & 19.03 & 0.07 & & \\
\hline
\end{tabular}

\begin{tabular}{lrllrr}
\hline & df & Sum of squares & Mean of squares & F value & $P$-value \\
\hline Ignition source & 1 & 6.119 & 6.119 & 70.486 & $<0.001$ \\
Wind speed & 2 & 1.952 & 1.952 & 22.478 & $<0.001$ \\
Source of ignition * & 2 & 0.169 & 0.169 & 1.945 & 0.164 \\
$\quad \begin{array}{l}\text { Wind speed } \\
\text { Residuals }\end{array}$ & 266 & 23.093 & 0.087 & & \\
\hline
\end{tabular}

\begin{tabular}{lllll}
\hline & Ignition moisture & Spread moisture & Ignition source & Wind speed \\
\hline Ignition moisture & 1 & & & \\
Spread moisture & 0.94 & 1 & 1 & \\
Source of ignition & -0.56 & $-0.45^{* * *}$ & 0 & 1 \\
Wind speed & $0.27^{* * *}$ & $0.25^{* * *}$ & & \\
\hline
\end{tabular}




\section{Discussion}

The purpose of this study was to determine the critical moisture extinction point of various fuel types to ignite and to spread fire when fuels are lit by matches or by cigarette butts. The results support observations in the laboratory analysis of fuel moisture content thresholds at time of ignition and rate of spread of fire. A significant difference was observed between the ignition threshold and the fire spread threshold (Student's test). The results also indicate that both ignition and fire spread thresholds depend on fuel type (see ANOVA results). The results show that the occurrence of fire does not necessarily lead to the spread of fire due to several key factors such as fuel moisture content thresholds, wind speed, and slope.

The ignition and fire spread threshold values of fuel species in this study are in agreement with the $10 \%-40 \%$ range established by Rothermel (1972)and validate more recent research (Chuvieco et al. 2004; Santana and Marrs 2014). A variability of ignition and fire spread thresholds was observed, ignition thresholds between $10.5-40.4 \%$ and fire spread thresholds between 9.7-38.9\%. Fuel species from the genera Betula, Picea, Pinus, Acer, Juglans, Larix, and Ulmus promote ignition and sustain fire spread under higher or slightly higher levels of fuel moisture levels than other fuel species (26.4-40.4\% for ignition, and $16.1-38.9 \%$ for fire spread). For the remaining fuel types, (e.g., Syringa reticulana, Acer ginnala, Betula platyphylla-Quercus mongolica, Populus davidiana) ignition and fire spread thresholds were in the range of $11.0-25.4 \%$ and $9.7-16.9 \%$, respectively. Our results confirm the variability of ignition and fire spread thresholds of different fuel types in previous studies: 8\% for Eucalyptus pachyloma and E. tetragona (McCaw 1995); 20-25\% (in the absence of wind) and 25-30\% (with wind) for Pinus radiata (Woodman and Rawson 1982); $30 \%$ for Pinus radiata (Plucinski and Anderson 2008); 35\% for $P$. pinaster (Fernandes et al. 2008); and 36\% for Ulex europaeus (Anderson and Anderson 2010). Bradstock s et al. (2012) reported that eucalypt litter fuels did not ignite when moisture content was higher than $28 \%$. In addition, when the moisture content was between 22 and $28 \%$, ignition and fire spread were difficult. However, when moisture content was between $16-22 \%$, pine fuels ignited and burned readily. Other studies related to the inflammation threshold are described in Plucinski (2003) for species of the genera Pinus, Eucalyptus, and Picea.

In this study, the fire spread moisture threshold is defined as the moisture of extinction, as determined by Rothermel (1972), as the fuel moisture content above which fire cannot spread or be sustained. Ignition and fire spread moisture thresholds differ for all fuel species. Therefore, species with low ignition and spread moisture thresholds should be interplanted with those with high thresholds to reduce the risk of fire ignition and spread. As reported by Valette (1990), the abundance of species with low ignitability will have the effect of reducing the combustibility of the plantation; in contrast, the richness of highly inflammable species renders the mixture plantations greater combustibility. These results are in agreement with previous findings (Weise et al. 2005; Plucinski and Anderson 2008; Ganteaume et al. 2011), which underlined the variations among fuel types to ignite or to spread fire. They also confirm the results of Cawson and Duff (2019) and Ganteaume et al. (2009) that flammability of dead fuels is related to the chemical composition of species and/or to meteorological conditions. Mixed and broadleaf stands were characterized by slightly lower ignition point and spread thresholds than pure coniferous stands; this is consistent with the findings of Liu et al. (2012).

Laboratory experiments under controlled conditions have the advantage of producing more accurate results than field experiments (Davies and Legg 2011), but their results do not accurately reflect real-world situations. Although laboratory experiments are not surrogates for field fires (Fernandes and Cruz 2012), the findings of this study are a contribution to improved forest fire management. Thus, further laboratory and field experiments on dead and live fuels are needed to establish the relationships among ignition and fire spread moisture content thresholds with slope, wind speed, time of ignition, fire spread, and fuel chemical composition variables. The findings of this study suggest the benefits of mixed species plantations to reduce fuel hazard and fire risk, as some fuel types at $12 \%$ moisture content ignite but do not result in fire spread, while others up to $25 \%$ do. As a result, mono-specific plantations are predisposed to burn more readily than natural forests. The results also suggest that forest fire managers should pay particular attention to the respective thresholds of each fuel type when carrying out a prescribed burn. Information from this laboratory experiment should provide fire managers in northeast China greater understanding of the requirements of prescribed burning and the level of good-practice guidelines, allowing them to adjust management to meet the criteria (Charles and Garten 2006; Wang et al. 2013). This will contribute to the preservation of both biodiversity and the provision of ecosystem services (Allen et al. 2016). The present work did not consider other variables that may influence fire development, such as the density of fuels, fuel proportions (in the case of mixed fuels), fuel age; thus, experimentation including these factors is needed in future research.

\section{Conclusion}

Using matches and cigarette butts, variability of ignition and fire spread thresholds were observed, with an ignition moisture content threshold $10.5-40.4 \%$ and a fire spread moisture 
content threshold 9.7-38.9\%. Fuels at different moisture contents ignited according to the species, wind speed, and ignition source (matches or cigarette butts). Some fuel species at $15 \%$ moisture content did not ignite, whereas other species ignited at $40 \%$ moisture content and fire spread at $38 \%$ moisture using matches, or ignited at $27 \%$ moisture levels and the fire spread at 25\% moisture content using cigarette butts. Wind speed and ignition source had a significant effect on ignition and fire spread and may be analyzed independently from one another. Matches were more effective at igniting and spreading fire with fuels with high moisture levels than cigarette butts. Although ignition and fire spread thresholds were measured using laboratory experiments, the estimated threshold for each fuel type remains a useful indicator for defining when fire hazards may occur in a forest. The best way to mitigate fire risk in forest plantations is through mixing species with low ignition threshold with those with a high threshold.

Acknowledgements This research was financially supported by the National Key Research and Development Program of China (No.2018YFE0207800, No. 2018YFD0600205) and Fundamental Research Funds for the Central Universities (No. 2572017PZ05, No. 2572019CP10). We greatly appreciate the "Northern Forest Fire Management Key Laboratory" of the State Forestry and Grassland Bureau and the "National Innovation Alliance of Wildland Fire Prevention and Control Technology", China, for supporting this research. We are grateful to the anonymous reviewers to help improve the quality of the manuscripts and to Mr. Vitekere for producing the map of the study location.

\section{Compliance with ethical standards}

Conflict of interest The authors declare no conflict of interest.

Open Access This article is licensed under a Creative Commons Attribution 4.0 International License, which permits use, sharing, adaptation, distribution and reproduction in any medium or format, as long as you give appropriate credit to the original author(s) and the source, provide a link to the Creative Commons licence, and indicate if changes were made. The images or other third party material in this article are included in the article's Creative Commons licence, unless indicated otherwise in a credit line to the material. If material is not included in the article's Creative Commons licence and your intended use is not permitted by statutory regulation or exceeds the permitted use, you will need to obtain permission directly from the copyright holder. To view a copy of this licence, visit http://creativecommons.org/licenses/by/4.0/.

\section{References}

Alessio GA, Penuelas J, Llusia J, Ogaya R, Estiarte M, De Lillis M (2008) Influence of water and terpenes on flammability in some dominant Mediterranean species. Int J Wildl Fire 17:274-286. https://doi.org/10.1071/WF07038

Allen KA, Denelle P, Ruiz FMS (2016) Prescribed moorland burning meets good practice guidelines: a monitoring case study using aerial photography in the Peak District, UK. Ecol Indic 62:76-85. https://doi.org/10.1016/j.ecolind.2015.11.030
Anderson HE (1970) Forest fuel ignitibility. Fire Technol 6:312-319. https://doi.org/10.1007/BF02588932

Anderson SAJ, Anderson WR (2010) Ignition and fire spread thresholds in gorse (Ulex europaeus). Int J Wildl Fire 19:589-598. https ://doi.org/10.1071/WF09008

Bradstock RA, Gill AM, Williams RJ (eds) (2012) Flammable Australia: fire regimes, biodiversity and ecosystems in a changing world. CSIRO publishing, Collingwood

Cawson JG, Duff TJ (2019) Forest fuel bed ignitability under marginal fire weather conditions in Eucalyptus forests. Int J Wildl Fire 28:198-204. https://doi.org/10.1071/WF18070

Chang Y, He HS, Hu Y (2008) Historic and current fire regimes in the Great Xing'an Mountains, northeastern China: implications for long-term forest management. For Ecol Manag 254:445-453. https://doi.org/10.1016/j.foreco.2007.04.050

Charles T, Garten JR (2006) Predicted effects of prescribed burning and harvesting on forest recovery and sustainability in southwest Georgia, USA. J Environ Manag 81(4):323-332. https:// doi.org/10.1016/j.jenvman.2005.11.005

Chuvieco E, Aguado I, Dimitrakopoulos AP (2004) Conversion of fuel moisture content values to ignition potential for integrated fire danger assessment. Can J For Res 34:2284-2293. https:// doi.org/10.1139/X04-101

Davies GM, Legg CJ (2011) Fuel moisture thresholds in the flammability of Calluna vulgaris. Fire Technol 47:421-436. https ://doi.org/10.1007/s10694-010-0162-0

Dimitrakopoulos AP (2001) A statistical classification of Mediterranean species based on their flammability components. Int J Wildl Fire 10:113-118. https://doi.org/10.1071/WF01004

Dimitrakopoulos AP, Papaioannou KK (2001) Flammability assessment of Mediterranean forest fuels. Fire Technol 37:143-152

Fernandes PM, Cruz MG (2012) Plant flammability experiments offer limited insight into vegetation-fire dynamics interactions. New Phytol 194:606-609. https://doi.org/10.111 1/j.1469-8137.2012.04065.x

Fernandes PM, Botelho H, Rego F, Loureiro C (2008) Using fuel and weather variables to predict the sustainability of surface fire spread in maritime pine stands. Can J For Res 38:190-201. https://doi.org/10.1139/X07-159

Figueroa S, de Rivera J, Jahn W (2019) Influence of permeability on the rate of fire spread over natural and artificial Pinus radiata forest litter. Fire Technol 55:1085-1103. https://doi. org/10.1007/s10694-019-00824-w

Finney MA, Cohen JD, Grenfell IC, Yedinak KM (2010) An examination of fire spread thresholds in discontinuous fuel beds $\mathrm{A}$. Int J Wildl Fire 19:163-170. https://doi.org/10.1071/WF07177

Fletcher TH, Pickett BM, Smith SG (2007) Effects of moisture on ignition behavior of moist California Chaparral and Utah leaves. Combust Sci Technol 179:1183-1203. https://doi. org/10.1080/00102200601015574

Ganteaume A, Lampin-Maillet C, Guijarro M (2009) Spot fires: fuel bed flammability and capability of firebrands to ignite fuel beds. Int J Wildl Fire 18:951-969. https://doi.org/10.1071/WF07111

Ganteaume A, Marielle J, Corinne LM (2011) Effects of vegetation type and fire regime on flammability of undisturbed litter in Southeastern France. For Ecol Manag 261:2223-2231. https:// doi.org/10.1016/j.foreco.2010.09.046

Guo F, Su Z, Wang G (2017) Understanding fire drivers and relative impacts in different Chinese forest ecosystems. Sci Total Environ 605-606:411-425. https://doi.org/10.1016/j.scito tenv.2017.06.219

Hu T, Sun L, Hu H (2017) Soil respiration of the Dahurian Larch (Larix gmelinii) forest and the response to fire disturbance in Da Xing' an Mountains, China. Sci Rep 7:1-10. https://doi.org/10.1038/s4159 8-017-03325-4 
Hu T, Hu H, Li F (2019) Long-term effects of post-fire restoration types on nitrogen mineralisation in a Dahurian larch (Larix gmelinii)forest in boreal China. Sci Total Environ 679:237-247. https://doi. org/10.1016/j.scitotenv.2019.05.008

Jervis FX, Rein G (2016) Experimental study on the burning behaviour of Pinus halepensis needles using small-scale fire calorimetry of live, aged and dead samples. Fire Mater 40:385-395

Larjavaara M, Kuuluvainen T, Tanskanen H, Venäläinen A (2004) Variation in forest fire ignition probability in Finland. Silva Fenn 38:253-266. https://doi.org/10.14214/sf.414

Li J, Song Y, Huang X, Li M (2015) Comparison of forest burned areas in mainland China derived from MCD45A1 and data recorded in yearbooks from 2001 to 2011. Int J Wildl Fire 24:103-113. https ://doi.org/10.1071/WF14031

Liu Z, He HS, Yang J (2012) Emulating natural fire effects using harvesting in an eastern boreal forest landscape of northeast China. J Veg Sci 23:782-795. https://doi.org/10.111 1/j.1654-1103.2012.01397.x

Liu Z, Yang J, He HS (2013) Identifying the threshold of dominant controls on fire spread in a boreal forest landscape of Northeast China. PLoS ONE 8:e55618. https://doi.org/10.1371/journ al.pone. 0055618

Liu Z, Chen JM, Jin G, Qi Y (2015) Estimating seasonal variations of leaf area index using litterfall collection and optical methods in four mixed evergreen-deciduous forests. Agric For Meteorol 209-210:36-48. https://doi.org/10.1016/j.agrformet.2015.04.025

Madrigal J, Hernando C, Guijarro M, Díez C (2009) Evaluation of forest fuel flammability and combustion properties with an adapted mass loss calorimeter device. J Fire Sci 27:323-342. https://doi. org/10.1177/0734904109102030

Marino E, Madrigal J, Guijarro M (2010) Flammability descriptors of fine dead fuels resulting from two mechanical treatments in shrubland: a comparative laboratory study. Int J Wildl Fire 19:314-324. https://doi.org/10.1071/WF08123

McAllister S, Weise DR (2017) Effects of season on ignition of live wildland fuels using the forced ignition and flame spread test apparatus. Combust Sci Technol 189:231-247. https://doi. org/10.1080/00102202.2016.1206086

McCaw WL (1995) Predicting fire spread in Western Australian mallee-heath. CALMScience pp. 35-42

Nelson RM, Hiers JK (2008) The influence of fuelbed properties on moisture drying rates and timelags of longleaf pine litter. Can J For Res 38:2394-2404. https://doi.org/10.1139/X08-078

Nelson Jr RM (2001) Water relations of forest fuels. In: Forest fires. Elsevier, pp 79-149

Nolan RH, Boer MM, Resco De Dios V (2016) Large-scale, dynamic transformations in fuel moisture drive wildfire activity across southeastern Australia. Geophys Res Lett 43:4229-4238. https:// doi.org/10.1002/2016GL068614

Plucinski MP (2003) The investigation of factors governing ignition and development of fires in heathland vegetation. $\mathrm{PhD}$ thesis Univ New South Wales, Australia

Plucinski MP, Anderson WR (2008) Laboratory determination of factors influencing successful point ignition in the litter layer of shrubland vegetation. Int J Wildl Fire 17:628-637. https://doi. org/10.1071/WF07046

Plucinski MP, Anderson WR, Bradstock RA, Gill AM (2010) The initiation of fire spread in shrubland fuels recreated in the laboratory. Int J Wildl Fire 19:512-520. https://doi.org/10.1071/WF09038
Possell M, Bell TL (2013) The influence of fuel moisture content on the combustion of Eucalyptus foliage. Int J Wildl Fire 22:343-352. https://doi.org/10.1071/WF12077

Rossa CG (2018) A generic fuel moisture content attenuation factor for fire spread rate empirical models. For Syst 27:2. https://doi. org/10.5424/fs/2018272-13175

Rothermel RC (1972) A mathematical model for predicting fire spread in wildland fuels. Intermountain Forest \& Range Experiment Station, Forest Service, U.S. Dept. of Agriculture

Santana VM, Marrs RH (2014) Flammability properties of British heathland and moorland vegetation: models for predicting fire ignition. J Environ Manag 139:88-96. https://doi.org/10.1016/j. jenvman.2014.02.027

Su Z, Hu H, Wang G, Ma Y, Yang X, Guo F (2018) Using GIS and random forests to identify fire drivers in a forest city, Yichun, China. Geomatics Nat Hazards Risk 9:1207-1229. https://doi. org/10.1080/19475705.2018.1505667

Su Z, Tigabu M, Cao Q, Wang G, Hu H, Guo F (2019) Comparative analysis of spatial variation in forest fire drivers between boreal and subtropical ecosystems in China. For Ecol Manag 454:117669. https://doi.org/10.1016/j.foreco.2019.117669

Sun P, Zhang Y, Sun L, Hu H, Zhang H (2018) Influence of fuel moisture content, packing ratio and wind velocity on the ignition probability of fuel beds composed of Mongolian oak leaves via cigarette butts. Forests 9:507. https://doi.org/10.3390/f9090507

Syphard AD, Rustigianromsos H, Mann ML, Conlisk E, Moritz MA, Ackerly DD (2019) The relative influence of climate and housing development on current and projected future fire patterns and structure loss across three California landscapes. Glob Environ Chang 56:41-55. https://doi.org/10.1016/j.gloenvcha.2019.03.007

Valette JC (1990) Inflammabilités des espèces forestières méditerranéennes. Conséquences sur la combustibilité des formations forestières. Rev For Fr 42:76-92. https://doi.org/10.4267/2042/26171

Wang F, Li J, Zou B, Xu X, Li Z (2013) Effect of prescribed fire on soil properties and $\mathrm{N}$ transformation in two vegetation types in South China. Environ Manage 51:1164-1173. https://doi.org/10.1007/ s00267-013-0044-6

Weise DR, Zhou X, Sun L, Mahalingam S (2005) Fire spread in chaparral- 'Go or no-go?'. Int J Wildl Fire 14:99-106. https://doi. org/10.1071/WF04049

Woodman M, Rawson R (1982) Fuel reduction burning in radiata pine plantations. Fire Management Branch, Department of Conservation and Environment, Research report No 14. (Melbourne)

Wu ZW, He HS, Chang Y (2011) Development of customized fire behavior fuel models for boreal forests of Northeastern China. Environ Manage 48:1148-1157. https://doi.org/10.1007/s0026 7-011-9707-3

Yang G, Di XY, Guo QX (2011) The impact of climate change on forest fire danger rating in China's boreal forest. J For Res 22:249-257. https://doi.org/10.1007/s11676-011-0158-8

Ying L, Han J, Du Y, Shen Z (2018) Forest fire characteristics in China: spatial patterns and determinants with thresholds. For Ecol Manag 424:345-354. https://doi.org/10.1016/j.foreco.2018.05.020

Publisher's Note Springer Nature remains neutral with regard to jurisdictional claims in published maps and institutional affiliations. 